УДК 655.3.022.11

\title{
ЕФЕКТИВНІСТЬ СУМІСНОГО ВИКОРИСТАННЯ ДРУКАРСЬКИХ І ОЗДОБЛЮВАЛЬНИХ МОДУЛІВ ДЛЯ ВИГОТОВЛЕННЯ ПОЛІГРАФІЧНОЇ ПРОДУКЦіЇ
}

() І. С. Коркішко, магістр, Ю. О. Шостачук, К.т.н., доцент, нтУУ «КПІ», Київ, Україна

Статья посвящена проблемам и перспективе использования разных способов печати и отделки в едином технологическом процессе для получения качественной и внешне эксклюзивной печатной продукции.

The article is devoted problems and prospect of use of different ways of the press and furnish in one technological process for reception qualitative and outwardly refined printed production.

\section{Постановка проблеми}

Світовий ринок поліграфії, а також і України, постійно змінюється. Цей процес характеризується зменшенням накладів видань, збільшенням частки багатокольорової продукції та використанням декоративних елементів в оформленні та оздобленні продукції, а також скороченням часу виготовлення і зростанням вимог до якості кінцевого продукту. Ці зміни можуть бути ефективними за рахунок використання у єдиному процесі різних способів друкування та додавання різноманітних ефектів оздоблення при виготовленні продукції. Для цього необхідні машини, в яких можуть поєднуватися різні способи друку та оздоблення зі збереженням виробничих параметрів на заданому рівні. Це забезпечується при створенні потокових автоматизованих ліній з широким використанням автоматики та сучасних досягнень електроніки. Застосування такого обладнання набуває широкого вжитку для виготовлення складної продукції: етикеток, пакування, сувенірної продукції, плакатів, наклейок і т.п. на різноманітних матеріалах, починаючи від тонких плівок і закінчуючи важкими картонами. Складність виготовлення подібної продукції полягає в одночасному використанні багатьох видів друку, включаючи цифровий, з секціями нумерації, тиснення, ламінування, різу і гарячого або холодного тиснення фольгою. Кожна секція повинна узгоджено працювати з іншими ділянками машини, які можуть мати абсолютно різні технічні характеристики, наприклад тиску, швидкості тощо. До того ж, така продукція вимагає дотримання вимог багатьох стандартів (це стосується, зокрема, харчової упаковки і етикетки), характеризується високим ступенем захисту і складними ефектами оздоблення. 


\section{Аналіз попередніх досліджень}

Для друку пакувальної та етикеткової продукції використовуються всі види та способи друку. Підвищення захисних властивостей поверхні надрукованої продукції від механічних ушкоджень, підвищення виражених оптичних ефектів (глянцю), а також покращення умов подальшої обробки $є$ одним з пріоритетних напрямків подальшого розвитку поліграфії. Це досягається додатковим облагороджуванням друкарської продукції на спеціалізованому устаткуванні з використанням відповідних технологій, а також безпосередньо в друкарських машинах, оснащених секціями для нанесення лаків та паст перед або упродовж всього процесу друкування. Необхідність підвищення якості друкованої продукції та ії індивідуальність призвела до оснащення друкарських машин додатковими лакувальними та оздоблювальними секціями. Завдяки лакуванню підвищується та досягається така степінь глянцю, яка характерна фотографії, а використання декількох видів лаку як глянцевого, так і матового дозволяє збільшити контраст i, таким чином, збільшити ефект візуального сприйняття зображення і прискорити післядрукарську обробку відбитків, а також значно підвищити їх механічну міцність і оптимізувати подальше післядрукарське оздоблення продукції $[1,2]$.

Гібридні друкарські системи створюються методом поєднання модулів друкування та оздоблення із різних способами на- несення фарби, лаку і плівок та виконання оздоблення в одному технологічному процесі [3].

\section{Мета дослідження}

Метою даного дослідження є аналіз можливостей та ефективності поєднання різних видів друку та використання додаткових оздоблювальних пристроїв в одному технологічному циклі для виготовлення різноманітної поліграфічної продукції.

\section{Результати проведених досліджень}

Конструкція гібридних машин залежить від особливостей призначення машин і остаточного виду запланованої продукції, а також від можливостей поєднання друкарських і оздоблювальних секцій.

Особливе значення при створенні комбінованих друкарських систем мають технічні характеристики окремих способів друку та додаткового оздоблення, а також властивості задрукованних матеріалів, які повинні відповідати вимогам використовуваних технологій і способів друку та оздоблення [3].

Гібридні друкарські системи мають модульну побудову. Сьогодні існують друкарські системи, де поєднуються друкарські та лакувальні пристрої для суцільного та вибіркового лакування віддрукованої продукції; офсетний, флексографічний, трафаретний та безконтактні способи друку з можливістю використання модулів для тиснення фольгою, лакування, каширування тощо. 
Причому такі комбінації дозволяють використовувати для друку як декоративні, так і спеціальні фарби і лаки. Використання таких друкарських систем забезпечує високу якість продукції на різноманітних матеріалах, наприклад на одній і тій самій машині можна задруковувати: стандартний або етикетковий папір 3 використання традиційних офсетних фарб, дисперсного лаку та лаку Metalure; металізований папір з використанням покривних білил, традиційних фарб та дисперсного лаку; плівкових матеріалів з використанням УФбілил, фарб та лаків тощо.

Цікавою є конструкція машин з використанням флексографічного способу друку перед секціями офсетного друку. При цьому на поверхню за допомогою флексосекцій наноситься «Праймер (основа)», що дозволяє вирівняти властивості поверхні і створити унікальні можливості щодо зовнішнього вигляду продукції при подальшому нанесенні фарби та лаків.
На рис. 1 приведена, як приклад, машина Galus E 410 фірми «Galus». Машина оснащена секціями офсетного, флексографічного і трафаретного друку, а також секцією гарячого тиснення, модулем для ламінування та припресування плівок. Машина оснащена також пристроями для висікання і викладу виготовленої продукції. Станина агрегату має приводні елементи для підключення пристроїв і модулів в необхідній конфігурації. Секції висічки можуть бути замінені на секції вирубки для переробки картонів. Прямий сервопривод друкарських секцій дозволяє змінювати параметри друку з головного пульта, не прив'язуючись до діаметру формної гільзи. Максимальна швидкість друкування становить близько 180-250 м/Хв. Конструкція машини має відкриту архітектуру.

Основним способом друку гібридних машин є флексографічний [3]. Це пояснюється відносною конструктивною про-
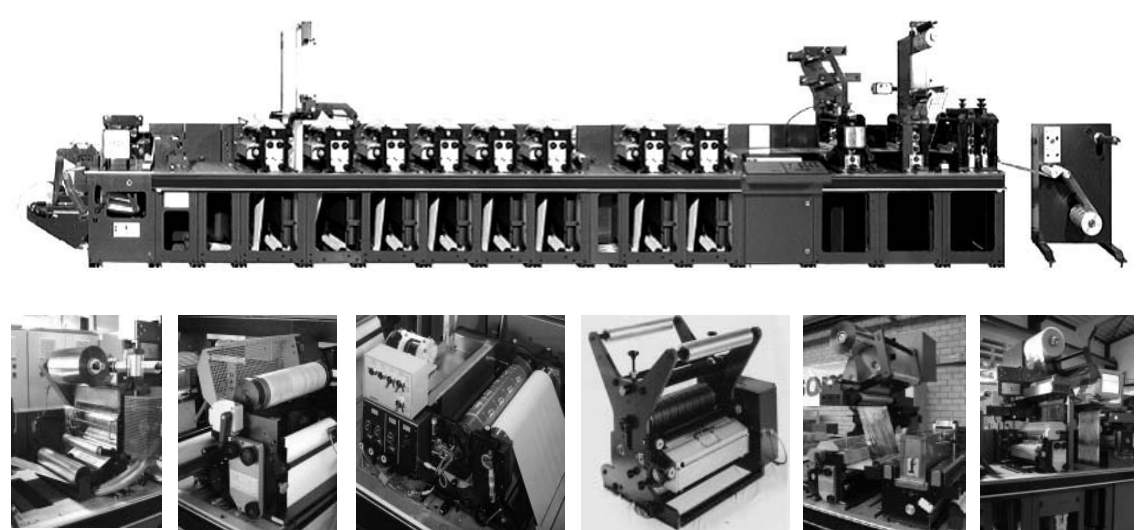

Рис. 1. Гібридна друкарська машина з секціями флексографічного, офсетного і трафаретного способів друку та гарячим тисненням фольгою 
стотою машин флексографічного способу друку та використанням еластичних форм. При необхідності отримання високої якості використовується офсетний спосіб друку, який дозволяє використовувати різноманітні по структурі на хімічному складу фарби і лаки. Високу якість забезпечує також високий спосіб друку, але на відміну від офсетного, високий друк $є$ чутливим до характеру поверхні паперу. Забезпечення високої якості у високому способі друку відбувається за рахунок створення високого тиску, що, з одного боку призводить до вирівнювання поверхні паперових матеріалів, а з іншого може руйнувати та спотворювати структуру матеріалу [3]

Для забезпечення додаткових єфектів використовується трафаретний спосіб друку. Особливостями трафаретного друку $є$ відносно велика товщина фарбового шару на відбитку, що забезпечує відчуття рельєфності зображення, високу яскравість та насиченість зображень, у тому числі на грубофактурних поверхнях, таких як картон, шкіра, тканина, деревина, пластмаса, кераміка тощо, а також можливість задруковування поверхонь складної геометричної форми [4].

Останнім часом широкого вжитку набуває використання секцій цифрового (струминного) друку, який характеризується оперативністю та можливістю персоналізації інформації [5].

Для підвищення оптичного ефекту поверхні друкованих матеріалів широко використовуються лаки, а також додаткове ламінування фольгою.

Окремі види упаковки харчової продукції повинні мати особливу поверхню з специфічними властивостями для захисту та мінімізації процесу обміну між продуктом та зовнішнім середовищем, тобто забезпечувати відповідну герметичність. Це можливо шляхом нанесення на надруковану поверхню спеціальних захисних лаків та паст. Структурна схема можливої побудови гібридного устаткування приведена на рис. 2.
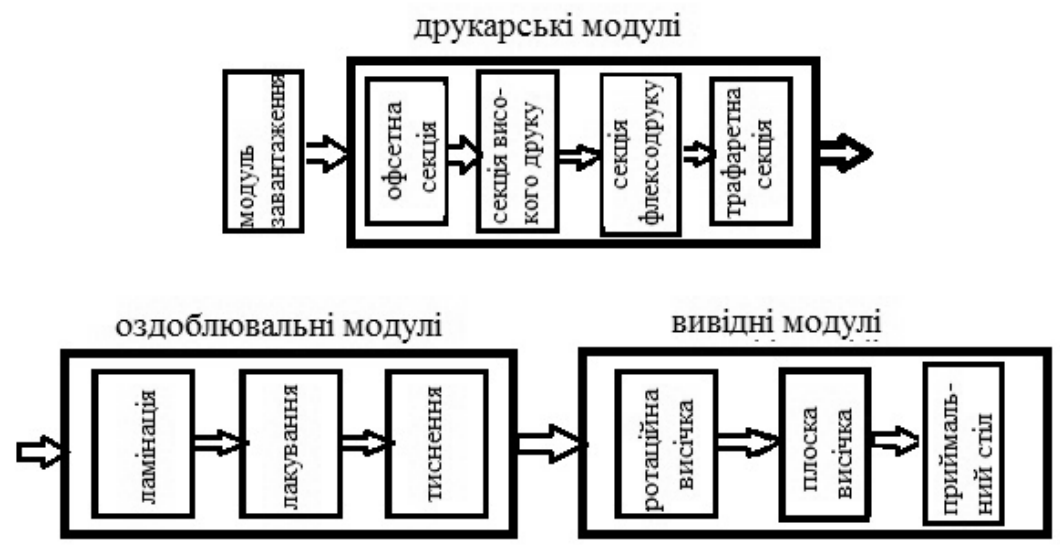

Рис. 2. Структурна схема побудови гібридного устаткування 
МАШИНИ І АВТОМАТИЗОВАНІ КОМПЛЕКСИ

Основні параметри та характеристики процесу та гібридного обладнання наведені в таблицях 1 і 2 [1-6].

Таблиця 1.

Характерні особливості основних способів друку

\begin{tabular}{|c|c|c|c|c|c|c|}
\hline $\begin{array}{c}\text { Ознака/ вид } \\
\text { друку }\end{array}$ & $\begin{array}{c}\text { Високий } \\
\text { друк }\end{array}$ & $\begin{array}{c}\text { Глибокий } \\
\text { друк }\end{array}$ & $\begin{array}{c}\text { Трафаретний } \\
\text { друк }\end{array}$ & $\begin{array}{l}\text { Флексогра- } \\
\text { фічний друк }\end{array}$ & Офсетний друк & $\begin{array}{c}\text { Цифровий } \\
\text { друк }\end{array}$ \\
\hline $\begin{array}{l}\text { Швидкість } \\
\text { друку }\end{array}$ & $\begin{array}{c}10-12 \\
\mathrm{M} / \mathrm{C}\end{array}$ & $\begin{array}{l}\text { до } 650 \\
\text { M/Хв. }\end{array}$ & $\begin{array}{l}\text { до } 80 \\
\text { M/Хв. }\end{array}$ & $\begin{array}{c}350-450 \\
\mathrm{M} / \mathrm{XB} .\end{array}$ & $\begin{array}{c}\text { до } 15 \\
\text { M/C }\end{array}$ & $\begin{array}{c}\text { до } 0,9 \\
\text { M/C }\end{array}$ \\
\hline Матеріали & $\begin{array}{c}\text { Папір, } \\
\text { картон, } \\
\text { полімери }\end{array}$ & $\begin{array}{c}\text { Целюлозні } \\
\text { синтетичні } \\
\text { металізовані } \\
\text { папери і } \\
\text { картони, } \\
\text { синтетичні } \\
\text { полімерні } \\
\text { матеріали }\end{array}$ & $\begin{array}{c}\text { Грубофак- } \\
\text { турні поверх- } \\
\text { ні, картон, } \\
\text { шкіра, ткани- } \\
\text { на, деревина, } \\
\text { пластмаса, } \\
\text { кераміка }\end{array}$ & $\begin{array}{c}\text { Папір, картон, } \\
\text { полімерні ма- } \\
\text { теріали, фоль- } \\
\text { га, грубо фак- } \\
\text { турні ма- } \\
\text { теріали, по- } \\
\text { ліетиленова } \\
\text { плівка, скло. }\end{array}$ & $\begin{array}{c}\text { Папір, картон, } \\
\text { метал, } \\
\text { пластик. }\end{array}$ & $\begin{array}{l}\text { Папір, кар- } \\
\text { тон, плівка, } \\
\text { фольга, са- } \\
\text { моклейкий } \\
\text { папір, } \\
\text { полімерні } \\
\text { матеріали, } \\
\text { тканина. }\end{array}$ \\
\hline $\begin{array}{l}\text { Тиск при дру- } \\
\text { куванні, МПа }\end{array}$ & $5-15$ & $1,5-2$ & $0,015-0,06$ & $0,1-0,5$ & $0,8-2$ & до 0,1 \\
\hline $\begin{array}{l}\text { Фарба/ тов- } \\
\text { щина фарбо- } \\
\text { вого шару/ } \\
\text { в'язкість }\end{array}$ & $\begin{array}{c}\text { Високо- } \\
\text { в'язкі, } \\
\text { пасто- } \\
\text { подібні } \\
\text { фарби. } \\
\text { Товщина } \\
\text { фарбового } \\
\text { шару: } \\
\text { 0,5-1,5 мкм. } \\
\text { В'язкість: } \\
\text { 50-150 } \\
\text { Па*с }\end{array}$ & $\begin{array}{c}\text { Спеціальні } \\
\text { рідкі фарби: } \\
\text { флуорес- } \\
\text { центні, ме- } \\
\text { талізовані. } \\
\text { Товщина } \\
\text { фарбового } \\
\text { шару: } \\
\text { 0,8-8 мкм. } \\
\text { В'язкість: } \\
\text { 0,05-0,2 } \\
\text { Па*с }\end{array}$ & $\begin{array}{c}\text { Широкий ряд } \\
\text { пастоподібних } \\
\text { фарб різної } \\
\text { густини і } \\
\text { складу (аро- } \\
\text { матизовані, } \\
\text { термофарби). } \\
\text { Товщина фар- } \\
\text { бового шару: } \\
100 \text { мкм. } \\
\text { В'язкість: до } \\
\text { 23,3 Па*с }\end{array}$ & $\begin{array}{c}\text { Спиртові і во- } \\
\text { дорозчинні } \\
\text { фарби для ви- } \\
\text { готовлення } \\
\text { харчових про- } \\
\text { дуктів } \\
\text { Товщина фарбо- } \\
\text { вого шару: до } \\
\text { 2,5 мкм. } \\
\text { В'язкість 0,05- } \\
\text { 0,5Па*с }\end{array}$ & $\begin{array}{c}\text { Пастоподібні, } \\
\text { високов'язкі } \\
\text { фарби. } \\
\text { Товщина фар- } \\
\text { бового шару: } \\
\text { 0,5-1,5 мкм. } \\
\text { В'язкістьдо } 40 \\
\text { Па*с }\end{array}$ & $\begin{array}{c}\text { Електрогра- } \\
\text { фічний друк } \\
\text { сухим та } \\
\text { рідким тоне- } \\
\text { ром. } \\
\text { Струминний } \\
\text { друк: рідкі } \\
\text { УФ-фарби }\end{array}$ \\
\hline $\begin{array}{l}\text { Потужність } \\
\text { сушки, Вт/см }\end{array}$ & $50-250$ & $100-300$ & $50-250$ & $50-250$ & $50-250$ & $50-250$ \\
\hline $\begin{array}{l}\text { Вид } \\
\text { продукції }\end{array}$ & $\begin{array}{l}\text { Газети, ло- } \\
\text { терейні } \\
\text { білети, ети- } \\
\text { кетки, до- } \\
\text { відники, } \\
\text { цінні папе- } \\
\text { ри }\end{array}$ & $\begin{array}{c}\text { Ілюстровані } \\
\text { журнали, } \\
\text { фотоальбо- } \\
\text { ми, порт- } \\
\text { рети }\end{array}$ & $\begin{array}{c}\text { Книжкова, } \\
\text { білова про- } \\
\text { дукції та па- } \\
\text { кування, ра- } \\
\text { діоелектроні- } \\
\text { ка, візитівки }\end{array}$ & $\begin{array}{c}\text { Етикетки, па- } \\
\text { кування, газе- } \\
\text { ти, шпалери, } \\
\text { паперові мішки, } \\
\text { друк на гофро- } \\
\text { картоні }\end{array}$ & $\begin{array}{c}\text { Газети, паку- } \\
\text { вання, книги, } \\
\text { рекламна } \\
\text { продукція }\end{array}$ & $\begin{array}{c}\text { Етикетки, } \\
\text { гнучка і кар- } \\
\text { тонна паку- } \\
\text { вальна про- } \\
\text { дукція тощо }\end{array}$ \\
\hline $\begin{array}{l}\text { Лініатура рас- } \\
\text { тру, лін./см }\end{array}$ & $40-140$ & $70-80$ & $25-50$ & $60-80$ & до 160 & 60 \\
\hline $\begin{array}{l}\text { Позитивні } \\
\text { сторони про- } \\
\text { цесу друку }\end{array}$ & $\begin{array}{c}\text { Чіткість } \\
\text { елементів } \\
\text { зображен- } \\
\text { ня, їх на- } \\
\text { сиченість } \\
\text { фарбою }\end{array}$ & $\begin{array}{c}\text { Найвища } \\
\text { якість при } \\
\text { передачі } \\
\text { півтонів. } \\
\text { Висока по- } \\
\text { вторюва- } \\
\text { ність кольо- } \\
\text { ру. Висока } \\
\text { тиражо- } \\
\text { стійкість } \\
\text { друкарської } \\
\text { форми. }\end{array}$ & $\begin{array}{c}\text { Рельєфність, } \\
\text { яскравість і } \\
\text { насиченність } \\
\text { зображення. } \\
\text { Можливість } \\
\text { задрукову- } \\
\text { вання повер- } \\
\text { хні складної } \\
\text { геометричної } \\
\text { форми. }\end{array}$ & $\begin{array}{c}\text { Висока тира- } \\
\text { жостійкість } \\
\text { друкарських } \\
\text { форм та велика } \\
\text { продуктивність } \\
\text { друку. Еко- } \\
\text { логічність, } \\
\text { низька енер- } \\
\text { гоємність, ма- } \\
\text { лий відсоток } \\
\text { відходів. }\end{array}$ & $\begin{array}{c}\text { Висока якість } \\
\text { друку, низька } \\
\text { собівартість, } \\
\text { висока про- } \\
\text { дуктивність, } \\
\text { швидке на- } \\
\text { лаштування } \\
\text { на друк. }\end{array}$ & $\begin{array}{c}\text { Відсутність } \\
\text { друкарських } \\
\text { форм, низька } \\
\text { вартість, } \\
\text { швидка зміна } \\
\text { завдань та } \\
\text { переналадка, } \\
\text { можливість } \\
\text { персона- } \\
\text { лізації. Яск- } \\
\text { равість і } \\
\text { насиченість } \\
\text { відбитків. }\end{array}$ \\
\hline $\begin{array}{l}\text { Недоліки } \\
\text { друку }\end{array}$ & $\begin{array}{l}\text { Висока } \\
\text { вартість } \\
\text { форм. } \\
\text { Низька } \\
\text { швидкість } \\
\text { друку. } \\
\text { Склад- } \\
\text { ність на- } \\
\text { лашту- } \\
\text { вання. }\end{array}$ & $\begin{array}{c}\text { Висока } \\
\text { вартість } \\
\text { форми }\end{array}$ & $\begin{array}{c}\text { Трудомісткість } \\
\text { формних про- } \\
\text { цесів. Низька } \\
\text { тиражостій- } \\
\text { кість форм. } \\
\text { Низька проду- } \\
\text { ктивність. } \\
\text { Тривала сушка. } \\
\text { Низька лініа- } \\
\text { тура растру. }\end{array}$ & $\begin{array}{c}\text { Еластичність } \\
\text { друкарської } \\
\text { форми може } \\
\text { призводити до } \\
\text { спотворення } \\
\text { відбитків. }\end{array}$ & $\begin{array}{c}\text { Складна конс- } \\
\text { трукція ма- } \\
\text { шини, про- } \\
\text { блеми друку } \\
\text { на полімерних } \\
\text { плів-ках і } \\
\text { фользі. }\end{array}$ & $\begin{array}{c}\text { Мала швид- } \\
\text { кість друку, } \\
\text { неможли- } \\
\text { вість друку- } \\
\text { вати пан- } \\
\text { тонними } \\
\text { фарбами, } \\
\text { висока вар- } \\
\text { тість при } \\
\text { великих } \\
\text { тиражах. }\end{array}$ \\
\hline
\end{tabular}




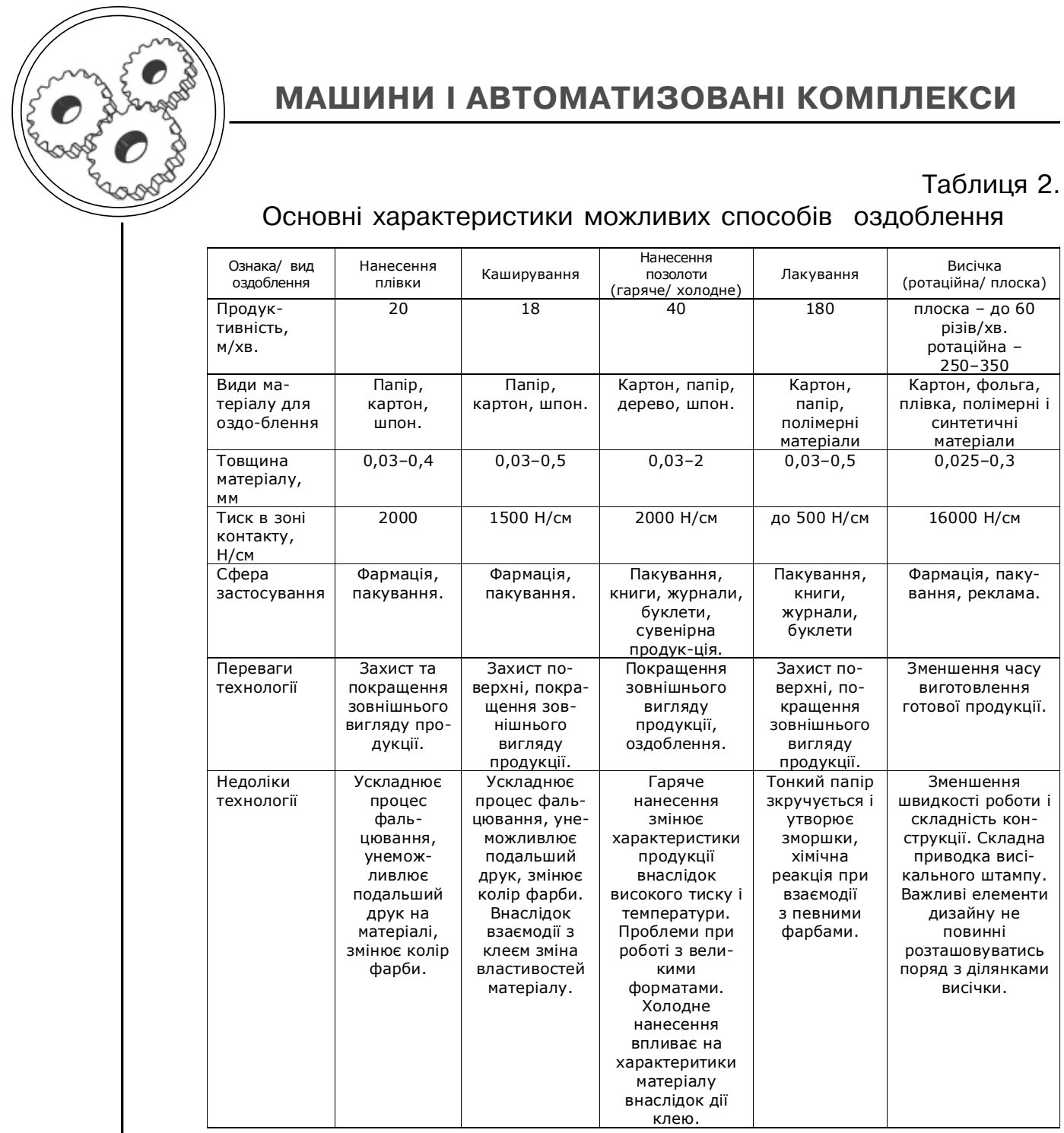

Методика оцінювання ефективності поєднання різних видів друку та секцій післядрукарського оздоблення в одному технологічному процесі

Ефективність роботи комбінованого гібридного устаткування залежить від кількості встановлених на машині технологічних модулів та їх характеристик. Для оцінки ефективності використання окремих модулів і пристосувань та гібридних машин в цілому були визначені наступні параметри:
- час налаштування відповідних модулів друку та оздоблення і машини в цілому. Вплив цього параметру визначаємо за допомогою коефіцієнта

$$
\mathrm{KH}=\Sigma \mathrm{THi} / \mathrm{TH} \text { г.C., }
$$

де Тні - час налаштування окремих одиниць, Тн г.с. - час налаштування гібридної системи. Коефіцієнт показує співвідношення витрат часу на налаштування та обслуговування розрізненого комплексу машин та 
окремих модулів у порівнянні 3 гібридною машиною;

- продуктивність (кількість отриманої продукції за годину роботи). Для цього знайдемо коефіцієнт продуктивності для окремих модулів і пристосувань та машини в цілому

Кп.од.уст. = n/( $\Sigma$ Трі + 2 Тді $)$;

$$
\text { Кп.к.с. }=\text { n/Tpi, }
$$

де $\mathrm{n}$ - кількість одиниць виготовленої продукції; Трі - робочий час виготовлення продукції; Тді - додатковий час, який необхідний для переміщення, складування, висушування тощо при виготовлені продукції на окремому обладнанню. Коефіцієнт показує співвідношення зміни часу виготовлення одиниці продукції при використанні окремих одиниць устаткування у порівнянні з гібридною машиною;

- споживання електроенергії. Для цього використаємо коефіцієнт співвідношення потужностей окремих модулів та пристосувань до потужності гібридної системи

$$
\mathrm{Ke}=\Sigma \mathrm{Ni} / \mathrm{Nr} \text {.c., }
$$

де $\mathrm{Ni}$ - потужність окремих модулів та машин; Nг.с. - потужність гібридної системи;

- вартість устаткування.

Вартість устаткування залежить від комплектації і визначається коефіцієнтом

$$
\text { Кв }=\Sigma \text { Ці/Цг.с., }
$$

де Ці - вартість окремих модулів та одиниць устаткування; Цг.с. - вартість гібридної системи;
- величина необхідної виробничої площі, яка визначається коефіцієнтом

Кр.п. = $\Sigma$ Sмі $+\Sigma$ Вві/Sг.с., (5)

де Sмі - встановлена площа машин; Sві - необхідна виробнича площа з врахуванням необхідності складування та перевезення продукції; Sг.с. встановлена площа гібридної машини;

- якість продукції при використання різних видів друку та оздоблення, яка характеризується кількістю браку. Для цього введемо коефіцієнт

$$
\text { Кб }=(\mathrm{m}-\mathrm{ni}) / \mathrm{m} \text {, }
$$

де $\mathrm{m}$ - величина накладу; $\mathrm{n}$ кількість одиниць готової продукції.

Результати проведених досліджень представлені у виді діаграм. Принципове порівняння визначених показників гібридного та розрізненого устаткування наведено на рис. 3 .

На схемі по вісях відкладені величини відповідних параметрів при виготовленні аналогічної продукції для гібридного устаткування (при сумісному використанні друкарських (офсет, флексо, трафарет) та оздоблювальних (лакувальних; ламінування; нанесення позолоти) секцій (лінія 1) і комплексу розрізненого друкарського і оздоблювального устаткування (лінія 2). Було досліджено також вплив секцій висікання: ротаційного та плоского.

На рис. 4. наведені порівняльні діаграми ефективності використання існуючих способів друку при їх поєднанні у складі гібридного та розрізненого ус-

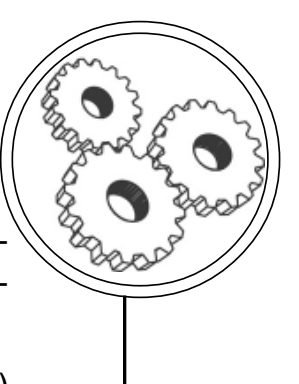




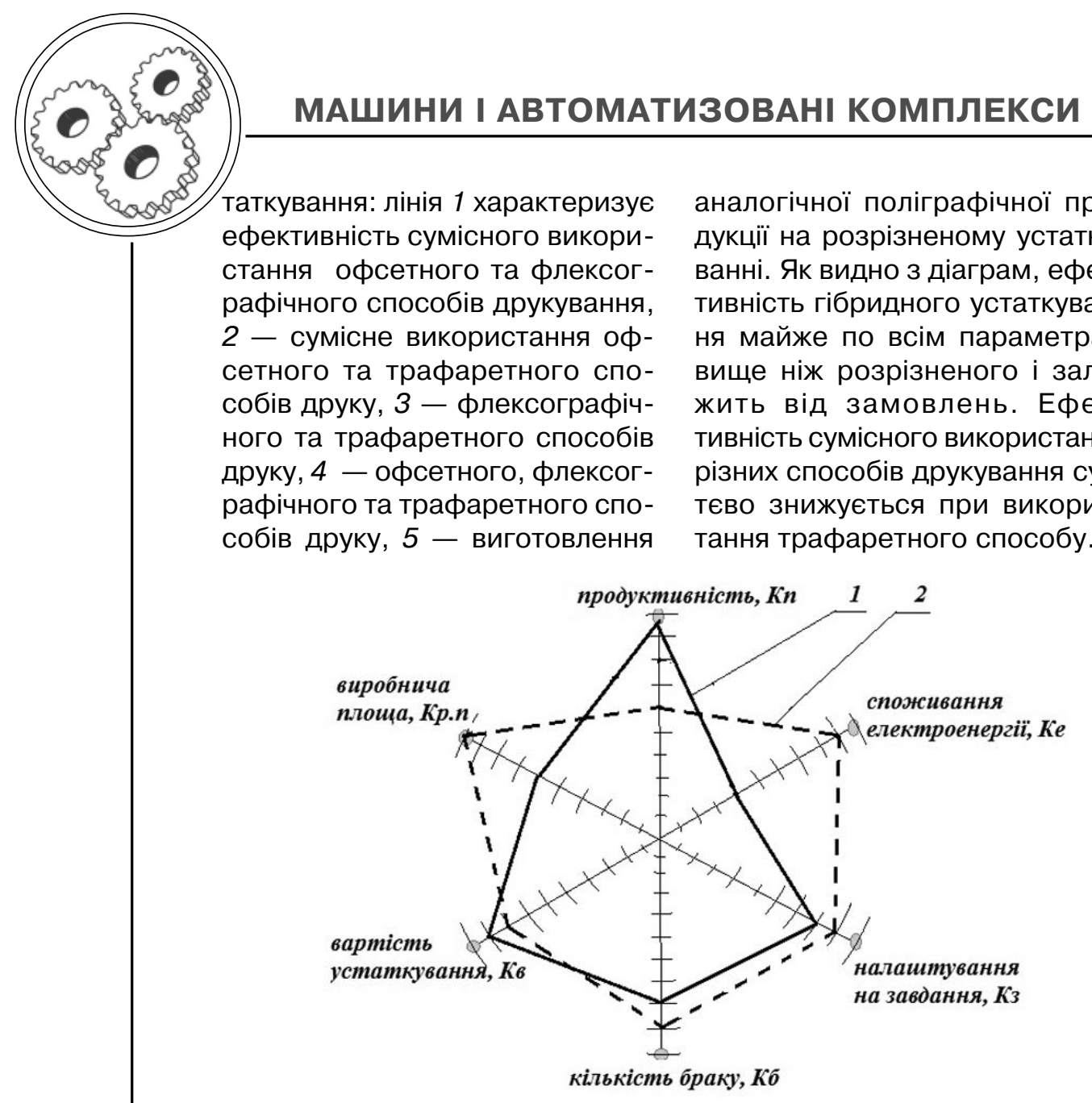

Рис. 3. Порівняльна схема ефективності використання гібридного (1) та розрізненого (2) друкарського і оздоблювального устаткування

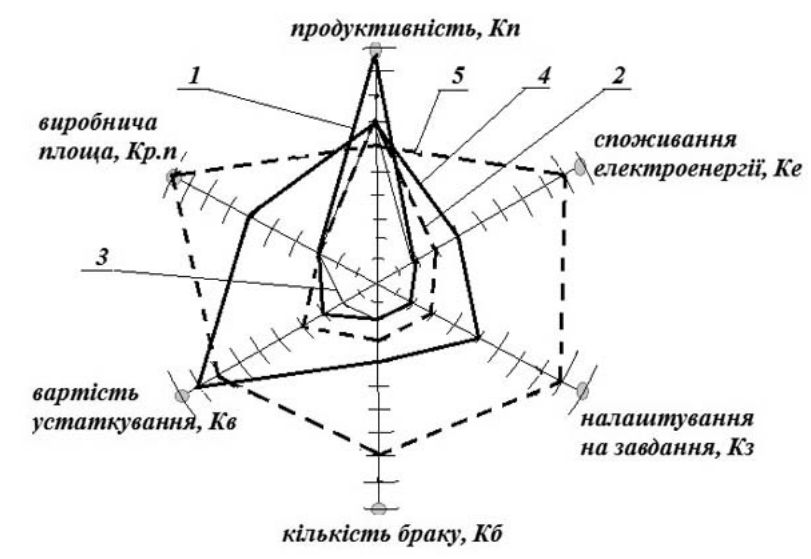

Рис. 4. Порівняльна схема ефективності використання різних способів друку гібридного та розрізненого устаткування 
На рис. 5. представлені порівняльні схеми ефективності використання гібридного устаткування за умов використання тих чи інших оздоблювальних секцій: лінія 1 - характеризує ефект роботу гібридної машини тільки при наявних друкарських секцій; 2 - характеризує роботу друкарських секції з секцією лакування; 3 - характеризує використання друкарських секцій 3 секцією ламінації; 4 - описує роботу друкарських секцій з секцією позолоти; 5 - характеризує роботи машини з плоскою висічкою.

Аналіз отриманих результатів показує, що вибір способу друку та оздоблення гібридного устаткування залежить від вимог до продукції, ії конструкції та наявності відповідних опцій.

Результати досліджень дають можливість оцінити ефективність поєднання і використання різнопланового гібридного устаткування.

\section{Висновки}

Розроблена методика визначення ефективності використання комплексного гібридного устаткування 3 використанням відповідних коефіцієнтів, що дозволяє отримати оптимальну 3 точки зору продуктивності конфігурацію машини, а також використати її при проектуванні і переоснащенні гібридних машин і уникнути додаткових технічних, економічних та енергетичних витрат під час організації та проведення технологічного процесу виготовлення поліграфічної продукції.

Варто підкреслити зручність роботи на гібридних машинах, на виході машини ми отримуємо готовий продукт, оздоблений, сфальцьований, обрізаний і т.п. Розрізнене устакування для виконання такої задачі вимагає набагато більше часу. До того ж, кожен технологічний розрив спричиняє погіршення привод-

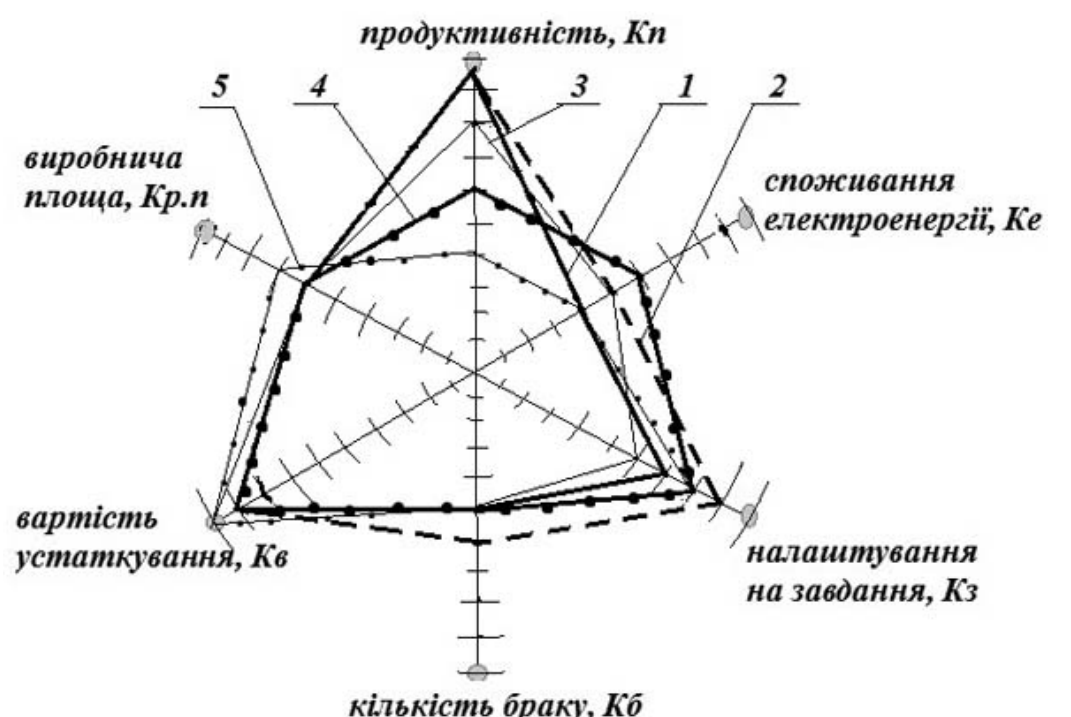

Рис. 5. Порівняльна схема ефективності роботи гібридного устаткування за умов використання різних оздоблювальних секцій 


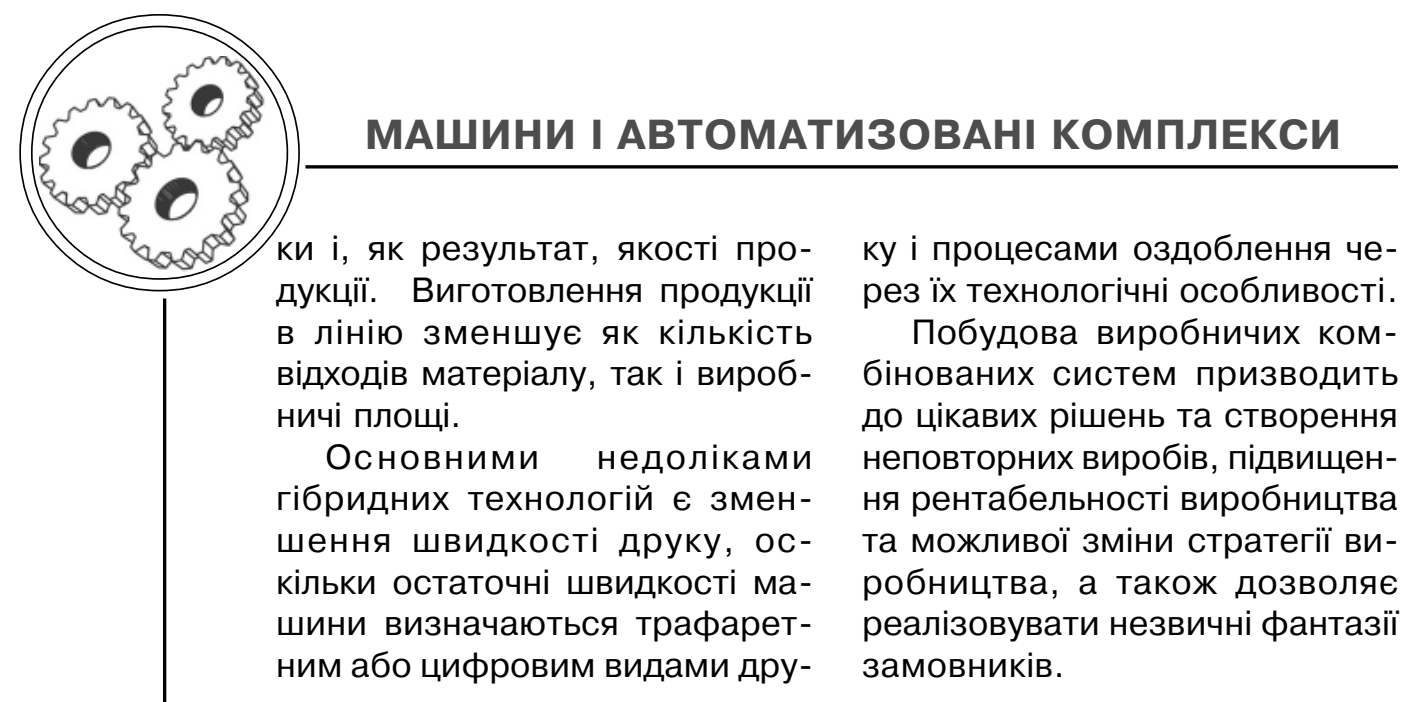

1. Шостачук Ю. О. Узагальнення напрямків сумісного використання в технологічному процесі різних видів друку / Ю. О. Шостачук // Технологія і техніка друкарства.- 2007. - № 17-18. - С. 23-29. 2. М. А. Степанець. Технологічні особливості виготовлення самоклеїльних етикеток на друкарсько-обробних лініях / О. В. Зоренко, А. І. Степанець // Техніка і технологія друкарства. - 2008 - № 3-4. - С. 102-108. 3. Киппхан Г. Энциклопедия по печатным средствам информации / Г. Киппхан. - М. : Московский государственный университет печати, 2003. - С. 9-10. 4. Ткачук М. П. Трафаретний друк / М. П. Ткачук. - К. : ХаГар, 2000. - 264 с. 5. «Print+».2011. - № 4 (78), № 7 (81). 6. Хведчин Ю. Й. Брошурувально-палітурне устаткування. Ч. І. Брошурувальне устаткування. Підручник / Ю. Й. Хведчин. - Львів : ТеРус. - 1999. - 336 с.

Рецензент -А. І. Іванко, к.Т.Н., доцент, НТУУ «КПІ»

Надійшла до редакції 23.03.12 